\title{
'The Similarity of Hue Constituted No Special Bond of Intimacy Between Them': Close Encounters of the Indigenous Kind
}

\section{LACHY PATERSON}

In 1901 Rēweti Kōhere, Anglican clergyman and editor of the Māori-language newspaper Te Pipiwharauroa, wrote the following words about Indian troops visiting New Zealand.

Ahakoa he iwi ke noa atu ratou, otira i te mea kotahi ano to tatou kingitanga, kotahi ano ta tatou kara e whawhai nei, ko te kara a to tatou Kuini kua tangohia atu nei, to tatou to ratou Kuini, e tata ana ano tatou.

[Although they are quite a different race, it is on account of us having one rule and one flag that is fought under, the flag of our Queen who has been taken from us, ours and their Queen, that we are close to them.] ${ }^{1}$

For Kōhere the bond between Māori and Indians was part of an imperial ideal, a family of races under a benevolent monarch, but was the 'closeness' he felt also linked to notions of a shared 'native' status, or of non-whiteness?

This essay discusses a set of encounters involving Indigenous peoples in Australia and New Zealand that were precipitated by the celebrations to mark the creation of the Australian Commonwealth in January 1901, and investigates how these were represented, and how some of the participants may have thought about these meetings. Although often considered primarily within Australian nationalist historiography, Federation was also an important imperial event. ${ }^{2}$ New Zealand dignitaries and troops, both of which contained Māori and Pākehā components, were present to celebrate the occasion. This might not have been unexpected: New Zealand had not yet rejected the prospect of becoming the seventh Australian state. However, the inclusion of detachments of British 'imperial' troops and Indian Army troops, who proved a highlight of the celebration, was definitely seen as explicitly linking the new Australian nation back to the British Empire. ${ }^{3}$ The Federation celebrations thus provided a number of opportunities for Indigenous peoples to meet. Māori chiefs who formed part of the official New Zealand party to the Sydney Federation celebrations encountered a group of Queensland Aborigines involved in a re-enactment of Cook's April 1770 landing at Botany Bay; Indian and Māori troops interacted at Sydney; and over a 25-day period in the summer of 1901, hastily arranged during the Australian celebrations, the Indian troops connected with Māori and Pākehā as they paraded through New Zealand towns and cities before their return to India. ${ }^{4}$

The 'intimacy' examined here is less concerned with physical acts, but with modes of familiarity, fraternity and notions of close connection that were often understood to underpin and foster the creation of imperial unity. I am concerned with how far these 'imperial intimacies' included Indigenous peoples, through a close examination of their involvement in an imperial event taking place on the peripherary of empire. A particular emphasis is placed upon Indigenous perspectives and understandings of imperial fraternity in action, and how those concerned viewed each other and how their own constructions of self-identity may have coloured these views.

However, this essay also seeks to unsettle the prevailing trope within historical writing that frames Indigenous encounters as occurring primarily with European colonizers. ${ }^{5}$ These interactions are often portrayed in terms of a false dichotomy - 
colonial mobility and hegemony on one hand and Indigenous passivity and victimhood on the other. In this characterization, colonization becomes a setting in which the 'local', 'rendered as static, comes to represent the immobility of "primitive" cultures and civilizations, relentlessly acted upon by those subjects who colonize via settlement or the sword'. ${ }^{6}$ While Europeans may be seen as natural inhabitants of colonial spaces, the foreign and mobile Indigene thus appears an anomaly, and potentially a threat to the expected norms of the colonizing ideal. Mobile Indigenous people also problematize national histories - such as New Zealand's, which is partly grounded on encounters and interactions between the components of the 'MāoriPākehā dyad'. ${ }^{7}$

The mobile 'native' was nothing new. Tony Ballantyne's 'webs of empire' were made of strands that carried not just ideas but also people - European and nonEuropean. ${ }^{8}$ European expansion through exploration, colonization and commerce created new opportunities for Indigenous individuals to travel to foreign lands. Captain Cook brought with him the Raiatean chief, Tupaia, on his first visit to New Zealand as a 'native informant' and interpreter, and other Oceanic travellers visited Britain, Europe, North America and many places in-between, either as crew, accompanying missionaries, or as guests of European governments. ${ }^{9}$ While often the encounters that Oceanic travellers experienced were with Europeans, there were also occasions when meetings occurred between Indigenous peoples. For example, Ngā Puhi chief, Te Pahi, observed and commented on Aborigines at Sydney in 1805; Ngāti Whātua chief Pāora Tūhaere sailed his own ship into the Pacific in 1863 to trade with the people of Rarotonga, and in 1907 Rēweti Kōhere interviewed a former governor of the Hawaiian kingdom, John Tamatoa Baker, about his homeland for Te Pipiwharauroa. ${ }^{10}$ Interactions could be less fleeting: for example, some individuals of Indigenous heritage also came and married into Māori communities in southern New Zealand. ${ }^{11}$ It is possible that many other Māori-Indigenous encounters may have occurred but were never been recorded. For instance, did Māori prospectors Hector Mānihera and Iriatara Kīngi meet any Indigenous North Americans when searching for gold in the Yukon at the end of the nineteenth century? ${ }^{12}$

The connections described above were largely organic in how they occurred, in most cases with Indigenous people moving as relatively free and autonomous agents. The intimacies produced by these travels might be messy, disorganized and disturbing to ideal colonial practice, but the shipping of Indigenous troops to enliven officially orchestrated events around the empire was somewhat different. When Māori and Indian troops featured at the Australian Federation celebration, when the Indians paraded down New Zealand streets, when Māori troops marched alongside the Duke of York at the opening of the Australian parliament in Melbourne, or 'native' soldiers, including Indian and Māori, attended the 1902 royal coronation, their presence was designed to align with the imperial ideology of a racial fraternity, and to reify colonial rule. ${ }^{13}$ In many respects, these events conformed to expectation, but nevertheless possessed the potential to disturb white hegemony. These transnational Indigenous interactions were potentially illuminating opportunities for 'native' self-examination. Federation offered a moment from which the participants might contrast and compare themselves with people whose lived experiences potentially matched their own, or may have assisted them in reflecting on their own place within the colonial societies that Europeans were constructing around them.

Given that first-hand accounts of these colonial meetings now only remain as 'texts' of either words or images, their 'reading' can be problematic. This essay relies 
heavily on press coverage from both sides of the Tasman to explore these disruptions. There is sometimes a chance to hear the Indigenous voice in such texts, although it is largely the Māori voice that is apparent. ${ }^{14}$ In particular Rēweti Kōhere's account in Te Pipiwharauroa on the Indians' visit to his town of Gisborne provides a genuinely Indigenous perspective in the Māori language. Kōhere represented the Anglican Church as the newspaper's editor, but also used this position to unofficially advance the agenda of the Young Maori Party that sought to uplift Māori socially, spiritually and materially, and to make gains for Māori within mainstream Pākehā institutions. ${ }^{15}$ These roles may have shaped his writing to some extent, similarly his chiefly status and educational attainment: in the hierarchy of historical evidence subaltern voices were frequently not reproduced and subsequently collected. In addition to the Indigenous voices we can also interpret reports written by Europeans about Indigenous-Indigenous encounters, although ever needful to carefully interrogate the sources. ${ }^{16}$ European commentators were attentive to how different Indigenous groups interacted with each other, and sometimes sought to illuminate occasions when shared indigeneity did not translate into empathetic understanding. However, as Alice Te Punga Somerville suggests, although the Indigenous-Indigenous encounter may 'not cut across the European gaze completely ... it certainly sidelines that gaze and produces spaces where its power is decentered'. ${ }^{17}$ Even when the 'European gaze' privileges what the authors considered was deserving of comment, their texts reveal some clues to what the subjects may have been thinking, feeling and experiencing.

\section{Pākehā attitudes to race}

Pākehā attitudes to race at the turn of the century were largely a product of their own sense of identity in which an incipient nationalism was developing alongside a high degree of imperial sentiment. These two components of identity did not appear contradictory to those who possessed them. For example, New Zealand was proud on both counts to send troops to South Africa as part of the British forces fighting the Boers. ${ }^{18}$ Pākehā were proud of their colonial progress, and perceptions of this experience, as well as cultural fetishizing of the distinct physical characteristics of the environment, helped construct an embryonic national identity. ${ }^{19}$ Despite increasing perceptions of the British Empire as a 'family' of different races, the emergent New Zealand nationalism shared with the Empire's other settler colonies a psychological and economic investment in the preservation of racial homogeneity. Fear of miscegenation led the New Zealand government not only to try to keep non-white immigrants out of the country, but ultimately formed one of the arguments against joining the Australian Federation. Notwithstanding strident calls within Australia to maintain its 'white' character, and its first federal legislation restricting the flow of non-white immigrants, the New Zealand government did not believe Australia could remain white enough, with its steaming tropics suitable only for darker races. ${ }^{20}$

In 1901 colonial New Zealand did not possess a significant Indian population. ${ }^{21}$ As the Auckland Star stated, 'Beyond the Chinese we in New Zealand are little troubled by visits from Asiatics. The Hindoo hawker is a rare sight in our towns or country places, but in Australia the case seems to be very different'. ${ }^{22}$ Nevertheless journalists and politicians generally viewed the presence of 'Asiatics', despite their numerical insignificance, as a potential threat to the demographic make-up and moral tone of colonial society. ${ }^{23}$ While the Nelson Evening Mail did not consider that New Zealand was about to be over-run by 'Asiatics', it argued that 'We do not want the 
inferior races here, and in due course we might increase the poll tax on them'. ${ }^{24}$ If most New Zealanders did not see many Indians (generally known as Hindoos regardless of religion) they nevertheless read about them in New Zealand's newspapers. 'Hindoo hawkers' were 'dangerous nuisances' and 'not a desirable fellow citizen', coming to the public's attention through court cases, although more often as victims of violence and fraud than as perpetrators. ${ }^{25}$ In the 1890 s, the press also kept New Zealand readers well informed on several high profile murders of Indian hawkers in Australia. ${ }^{26}$ Itinerant Indian hawkers, whether real or imagined, complicated the racial contours of a presumably 'white' colony. In 1896, a Labour Department report listed Indians as one of the undesirable races, and the New Zealand parliament read two bills, the Undesirable Hawkers Prevention Bill and the Asiatic Restriction Bill that could, if passed, have inhibited their entry and business. ${ }^{27}$ Three years later it passed the Immigration Restriction Act that was designed to discriminate against Indians, although they were often able to circumvent the restrictions. ${ }^{28} \mathrm{New}$ Zealand was not unique: Indians suffered discrimination in Britain's other 'white' colonies as well, especially South Africa. ${ }^{29}$

Despite antipathy to Indians, the idea of 'India' was nevertheless important to colonial New Zealand. Quite apart from some commerce between the countries driven by New Zealanders' predilection for tea, Tony Ballantyne suggests that 'India was a pivotal reference point in colonial intellectual culture'. ${ }^{30}$ This idea of 'India' could be both positive and negative. For some, it was a source of oriental wisdom, while for others a dark heathen space begging for missionary activity and European civilisation. ${ }^{31}$ India's relevance also lay in its importance to the empire, an entity that Pākehā New Zealanders saw themselves as much the heir to as the people living in the British Isles. India, not a colony but an 'empire' in its own right, was a fundamental component of the greater empire as can be seen in extensive metropolitan and colonial newspaper coverage of its affairs, especially defence. ${ }^{32}$ Bernard Porter posits that the importance of the 'Indian Empire' assisted more broadly in projecting the idea of empire in the late-nineteenth century. ${ }^{33}$ It is therefore not surprising that both New Zealand and Australia embraced the opportunity to host the visiting Indian troops as a means of engaging with the empire.

The presence of Māori in New Zealand further complicated the contradictions of an ethnically diverse empire but racially exclusive nation. The emergent New Zealand nationalism shared with the empire's other settler colonies a psychological and economic investment in the preservation of racial homogeneity. However just as New Zealand Pākehā saw their country as superior to Australia - in its environment, climate and quality of British settler - they also 'basked in the reflected glow' of a native people whom they deemed to be superior to other Indigenous peoples, partly through a supposed Caucasian ancestry but also through the level of civilization attained. ${ }^{34}$ This was largely an external projection or theoretical intellectual position: Pākehā generally had few qualms about how colonialism actually impacted on, or discriminated against Māori, and Māori themselves were well aware of the contradictions between the theory and practice. ${ }^{35}$ Although not all Pākehā were sympathetic to interracial unions, Māori-Pākehā marriage has been a constant within New Zealand's past. ${ }^{36}$ However, the size of the majority settler population, whose ranks were constantly being swelled by immigration, meant that felt the impact of interracial marriage was much more significant within the relatively smaller Māori population. ${ }^{37}$ Māori were thus an Indigenous other within the dominant Pākehā society, but sufficiently constrained to be non-threatening. 
Māori possessed - in theory - full rights as British subjects under the Treaty of Waitangi. ${ }^{38}$ In 1901 James Carroll, of Irish and Ngāti Kahungunu heritage, had recently taken over as Minister of Native Affairs from the Premier Richard Seddon: both men were sympathetic to Māori concerns where they did not impose upon the colony's economic and cultural progress. In particular the New Zealand government at this time urged Māori rights on the wider imperial stage. It sought to persuade the Australian government that Māori should not be treated the same as other non-white races in terms of entry into Australia. ${ }^{39}$ Similar concerns were raised during Federation discussions about the rights of Māori, considered 'a much higher race than the Australian aborigines'. ${ }^{40}$ Māori too were conscious of possible implications of Federation. A Te Pipiwharauroa editorial opined: 'In our opinion there is no benefit for us. ... because the Pākehā of Australia really despise the natives of that land, they will be unaccustomed to, and will be against Māori sitting in the Parliament. E koro, Seddon, leave us out of it! ${ }^{41}$ The status of Māori was also relevant to the larger colonial issue of the South African War. The New Zealand government argued against the British decision to exclude Māori soldiers from service in the South African War based on the desire to keep the conflict a 'white man's war'. ${ }^{42}$ According to one British newspaper, a Māori presence would only 'infuriate the Dutch', it would also 'insult our own Indian troops, who will regard it as a declaration of their inferiority to an inferior coloured race', a position hotly contested by some New Zealand newspapers on the basis of Māori racial superiority. ${ }^{43}$

\section{Tamahau Mahupuku meets Aborigines}

Three reasonably wealthy and influential Māori chiefs attended the Federation celebrations as part of James Carroll's entourage: Tamahau Mahupuku of Ngāti Kahungunu; Rātana (most likely Rātana Ngāhina of Ngāti Apa, a successful farmer and grandfather of the prophet T.W. Rātana); and Nireaha Tāmaki of Ngāti Hāmua. ${ }^{44}$ The government would have considered all three chiefs reliable and loyal. Mahupuku, for example, financially assisted the Wairarapa Mounted Rifle Volunteers, a local Māori corps, and offered to pay for a Māori force to South Africa. However, the loyalty of these chiefs did not mean that they did not contest aspects of colonial rule: both Mahupuku and Nireaha had been active in the Kotahitanga movement, which sought Māori autonomy under a national Māori Parliament, and Nireaha had fought an extended legal battle with the Crown over land issues. ${ }^{45}$

While in Sydney, Mahupuku arranged to be interviewed by the press and several New Zealand newspapers published his impressions of Sydney and the celebrations, including an account of a re-enactment of Captain Cook's landing (as interpreted by a Native Office employee). ${ }^{46}$ Participating in this event were 20 (or 25) 'trained aborigines' from coastal Queensland, who were also to 'give a display of corrobborees and the use of aboriginal weapons' ${ }^{47}$ The re-enactment, described by several Australian newspapers as a 'parody', 'absurd' and 'comedy', involved the Aborigines throwing spears, running away, emerging again, and finally 'a reconciliation took place between them and the white men.' ${ }^{48}$ It appears that Mahupuku may not have been directly introduced to the Aborigines.

I and my companions approached very close to them, so that we might see the make of those people and inspect their fighting weapons. I judged that they seemed to be a hardy set of men, but as to their faces I was unable to see them, as they were all covered with some kind of paint, so I was unable to judge. I saw, however, that their eyes were set far back in their sockets, 
while their eyebrows protruded and almost made a shadow. Their bodies were covered with hair and I noticed their fighting weapons were very dangerous. There were spears, boomerangs, and clubs that they use in battle. I may say that at this time I had in my possession a taiaha, and a great many pakehas wanted to feel it and see what it was like. Although the weapons of the Mungamunga [Mangumangu, blacks] were of various kinds and very numerous, the pakehas said that my taiaha was more picturesque than any of them, on account of its carvings, its mountings, and its feathers, also the greenstone symbol of Maori chieftainship was much admired by the people of the country, and our plumes of the huia, decorating our hats, greatly interested all who saw them. ${ }^{49}$

A Pākehā reporter also detailed the meeting for New Zealand newspapers.

What astonished the native mind and the other New Zealanders was the excellent English spoken by the Australians. "They beat us there," observed Mr Carroll. The three Maori chiefs stood off a little and in silence eyed the aboriginals. What they really thought no man knows. Asked what they thought they answered, "Very good" and expressed admiration for the physique of the aboriginals. Some of them were over six feet and very wiry looking. What did the Australian think of his Maori brother? In plain English one of them said he was no good. His stomach was too big, and this showed he drank too much beer. The Australian native has a contempt for a large-bellied person. Besides, the get-up of the Maori puzzled him. A brother savage in a bell-topper and a frock coat was too much for him, and this, added to his corpulence, settled the Maoris' claim to respectability in the Queensland natives' eyes. ${ }^{50}$

Neither account indicates close intimacy between the two groups but they differ on primary points of focus. Mahupuku's main concern was to demonstrate his chiefly status. He notes that Europeans were clearly able to discern the superior craftsmanship of his spear-club (taiaha). Similarly, he accentuates other cultural accoutrements admired by the Europeans, such as a piece of greenstone jewellery (perhaps a hei-tiki pendant) and feathers of the (now extinct) huia that denoted status in Māori society. While he made a point of describing the Aborigines' appearance in an almost ethnographic fashion, noting that they were 'hardy', he did not make any value judgments. Nor did he (other than in craftsmanship) suggest that Māori were superior to the Aborigines. It is difficult to know to what extent Māori accepted prevailing European beliefs in the hierarchy of races. Te Pipiwharauroa promoted a discourse of racial pride and once stated 'The black race of Australia is one of the lowest in the world, and it is said that the Māori race is the most noble of all the native races'. ${ }^{51}$ However, such discourse tended to revolve around cultural attainment rather than intrinsic racial characteristics. At times the paper identified with other Indigenous groups, or if it judged them did so according to its own ideologies, such as how far they might have advanced in civilization, how well they adhered to Christian values, or how well they were treated by whites. Racial hierarchies were not static, but ladders that could be climbed, or possibly fallen from. ${ }^{52}$

The second text stresses the lack of intimacy generated by the encounter. A European, observing the Māori and Aborigine observing each other, tried to elicit responses from each group. ${ }^{53}$ Rather unfairly perhaps, the Aborigines thought these 
Māori gentlemen of mature years a little too stout. Where Mahupuku saw traditional treasured items (taonga) that reflected his chiefly status as what differentiated him from the Aborigines, this article highlights aspects of modernity through which the two groups would compete: fluency in English, and the wearing of European clothing. It suggests that the Aboriginal commentator considered an Indigenous person in bell topper and frock coat as somewhat ridiculous. These clothes reflected wealth and status, and were considered suitable for respectable Victorian men, although eschewed by class-conscious workers. ${ }^{54}$ Such attire was not considered exceptional for wealthy Europeans but the fact that Mahupuku was renowned for this attire indicates that the image of a wealthy well-dressed Māori had not yet become normalized within New Zealand society. ${ }^{55}$ Nor perhaps in Aboriginal society. While wearing European clothing had long been considered a sign of civilizational advance for Māori, condescending comments on the novelty of how Māori wore them was also a not uncommon Pākehā practice of the nineteenth century. ${ }^{56}$ The newspaper article thus implies that it was indeed strange for Māori to wear such a 'get-up', while also buying into the 'fat Maori' stereotype of the time. ${ }^{57}$ Perhaps to assert his authority (mana), but undoubtedly with his tongue firmly in his cheek, it was reported by the Pākehā journalist that: 'As curiosities, one of the Maoris [stated that he] wanted to buy two of the aboriginals and take them home with him to New Zealand'.

\section{Māori and Indian troops in Sydney}

The Indian troops most likely first met Māori at the Australian Federation celebrations in Sydney. Māori accounts of the Indians were brief: Tamahau Mahupuku, in his account, stated that 'both [Indian and imperial troops] appeared so stately in their magnificent robes, their swords glittering like diamonds', and Charles Ferris, one of the Māori troops present reported to Te Pipiwharauroa, 'One important day was the military parade, at which the soldiers of England, the colonies and India marched: the uniforms were brilliant'. ${ }^{59}$ It was a Pākehā paper that sought to inflate notions of race with an account of a meeting of these two sets of 'native' soldiers, 'the only coloured races who took part in the military procession'. It noted that 'the similarity of hue constituted no special bond of intimacy between them', and that Māori efforts 'to be on more brotherly terms with the Indians' came to no avail. At one meeting some Māori performed an impromptu war dance (haka).

Not a shadow of astonishment touched the grave faces of the visitors as the stalwart forms leaped, gesticulated, and shouted before them. But, on the other hand, the Maoris showed just a little disappointment when their beturbaned and gorgeously arrayed visitors displayed not the least intention of performing a return dance. The latter merely bowed with great gravity and passed on.

According to the piece, the Māori were disappointed at the response, and when one suggested an even better haka next time, his comrades 'replied, somewhat despondently: "Ah, no good!"”60

An Australian newspaper also recounted Indian troops being treated to a Māori haka, suggesting a more organised affair.

The Maoris in camp are a fine body of men, well set up, and muscular. They gave a Maori welcome to the members of the Indian contingent on Saturday. The ceremony was a unique one. They indulged in a form of war dance, went through rapid evolutions, and suddenly finished by posing in tableau 
fashion, and gazing heavenwards. The interpreted meaning of the demonstration was - 'We greet you as comrades of the Queen, ready to fight alongside you for Queen and Empire. ${ }^{, 61}$

Rather than attempt to see two sets of 'natives' failing to communicate culturally, as the New Zealand paper had done, the South Australian Register instead stresses the imperial connection. Whereas the New Zealand press might praise Māori on the one hand as better than other 'natives', but deride them on the other hand for insufficient cultural refinement, the Australians saw the Māori - like the Indian troops - as a part of a larger imperial mosaic. The Australian journalists were enthusiastic about the Māori soldiers included within New Zealand's military contingents and extolled their fine physical condition: they appear to have been very popular and, on at least one occasion, 'treated the public to one of their war dances'. ${ }^{62}$

The haka, 'a vigorous, shouted dance', is an important signifier of Māori culture. Its purposes are varied, including to welcome, to express defiance, to make a political point, or to project the mana of the group performing it. By this time the haka had also become a performance piece and had, to some degree, attached itself to Pākehā conceptions of New Zealand identity. ${ }^{63}$ For example, as New Zealand troops paraded in Sydney prior to Federation Day, the Evening Post reported that 'little bands of New Zealanders made the proceedings lively with unrehearsed hakas'. ${ }^{64}$ The newspaper did not say whether the performers were Māori or Pākehā, or how authentic the haka were, however, by describing the participants as 'New Zealanders' and by not defining the word haka, we can assume that the practice was acculturated to some extent within the mainstream New Zealand society. Pākehā liked to portray Māori as representing 'the highest standard of any savage and aboriginal race under the sun', but it was more likely that the use of Māori cultural expressions such as the haka within late-nineteenth century New Zealand culture derived more from the desire to differentiate New Zealand from other settler societies, and to reflect a wildness now tamed. ${ }^{65}$ Ironically this appropriation lent mana to haka performances. Many Māori expected to be able to perform haka when welcoming dignitaries, or for local patriotic events. ${ }^{66}$ Pākehā generally appreciated these cultural displays so long as they were kept within the bounds of Victorian sensibilities. ${ }^{67}$

\section{Indian troops and Pākehā}

From their arrival in Auckland on 11 February 1901 to their departure almost a month later, the Indian troops proved very popular with the New Zealand public. The glamour, masculinity and patriotic ardor of the Indian troops convinced the New Zealand press to eschew its usual racialized disdain for foreign 'natives'. The utilitarian and largely homogenous nature of Pākehā colonialism no doubt paled in the face of the romantic Indian troops, whose sartorial elegance reflected the glamour of the British Raj. Newspapers used such phrases as 'Oriental munificence', 'decorated with Eastern profusion', 'a perfect picture of the rich, warm colours of the romantic East', and 'picturesque', and some gave long descriptions of the many different and sumptuous uniforms. Publications such as the Graphic, Otago Witness and Auckland Weekly News reproduced photographs of the parades and of the uniformed soldiers. Of particular note, was the 'handsome' and 'highly cultured' Colonel Dadbha. ${ }^{68}$

Heather Streets has argued that by the end of the nineteenth century a discourse of 'martial races' - a hierarchy of Indigenous military bravery and prowess in which Māori were considered to rank highly - sat naturally within an 'increasingly jingoistic, 
militaristic and imperially minded popular culture'. ${ }^{69}$ This discourse was evident in the New Zealand press in its reporting of the Indian troops. The Auckland Star extolled their military bearing, stressing that these handpicked men were 'splendid types of soldiers' and not 'toy soldiers'. ${ }^{70}$ The Poverty Bay Herald reflected these ideas with a section titled 'Best Fighting Races' within an extended article, which listed and described various Indian 'races', such as the 'tall bearded' and 'aristocratic' Sikhs, the 'essentially wild' Pathans, and 'Little Johnny Gurkha'. Although it suggested that 'the nature of the [Bengali] company is conducive to effeminacy, and physical sloth among the Bengalis is very marked', the Herald also later noted their distinguished record and 'valuable services'. Little was said of the servants who attended the soldiers, subaltern participants who lacked the glamour of their masters. The paper noted that their attire was 'worse for wear' and they 'were puny specimens of humanity compared with many of the sturdy warriors' ${ }^{71}$

Journalists and politicians also stressed the loyalty of the Indian troops to Queen Victoria and the imperial cause. The Poverty Bay Herald, for example, called on Gisborne residents to come to honour the Indians 'because they represent those who hold for us our Indian Empire, and who have spilt blood in upholding the name and honour of Britain', and the Auckland Star thought that Onehunga people 'looked upon the Indian troops as the bulwarks of the great empire from which they were drawn, just as the New Zealanders were themselves looked upon as a portion of Greater Britain', and the New Zealand Illustrated Magazine saw the troops as part of 'one world-wide band of brotherhood'. ${ }^{72}$ Seddon, hardly a supporter of 'Asiatics', declared that India was 'an integral portion of the Empire' that 'will ever remain a part of the British Empire', and believed that the Indian troops would 'fight to the last drop of blood to maintain [Victoria's] good son, the King, now on the throne'. ${ }^{73}$ Imperial fervour trumped the normal expositions on Hindu and Muslim 'idolatry', 'superstition' and 'cruelty', with discussions on the religious beliefs of the visiting soldiers tending to focus on the difficulty in providing them hospitality. ${ }^{74}$

The Pākehā public took the Indians to heart, treating them as celebrities. Citizens took advantage of the Indians' parades to decorate their streets in patriotic displays, and to assemble their own volunteer forces. ${ }^{75}$ Such was the Indians' celebrity status, that Dix's Gaiety Company advertised that the troops would be attending one of its Auckland performances as spectators. ${ }^{76}$ Some made a great effort to see them: upon finishing work a number of young men from Lawrence, keen to view the Indians, rode their bicycles overnight to Dunedin, a distance of almost 100 kilometres. 'The wonders of Dunedin were exploited, and the Indian troops gazed on with wonderment, and the return journey commenced in the evening'. ${ }^{77}$ While photographs show citizens posing with the Indian troops, this mixing appears constrained with little real closeness. Language difficulties may well have played a part, but their otherness may have been too wide a gap to bridge. Although there are no reports of 'wistful glances and endearing farewells' from women at the wharfs as was the case with the imperial touring troops, intimacies of other kinds did occur, reflecting the popular status of the Indian visitors. ${ }^{78}$ In Timaru 'a mania for handshaking took possession of the crowd of spectators, especially the feminine element. ... While passing along the street the Indian troops trailed their hands to allow people to touch them as they passed'. At the train station 'the track was lined with people for some distance, and they held up their hands to be stroked by the departing visitors' ${ }^{79}$ The Otago Witness was one of the few newspapers to look past the imperial glamour, and to query what the Indians might have been thinking. It 
suggested few spectators considered that the Indian population 'regard our reign as a passing cloud permitted for a moment to obscure the clear sky of Hindostan' after which they would quickly eschew any veneer of Western civilization. While the Indian troops were presently loyal to the monarchy and empire, 'it is doubtful whether they will be found on our side in the Battle of Armageddon' ${ }^{80}$

\section{Māori and Indians in New Zealand}

For Māori, at least those vocal in their loyalty to the empire, visits of distinguished guests to their locality were an opportunity to display aspects of their culture, allowing them to participate in wider community events on their own terms without the normal day-to-day expectations of assimilating into Pākehā cultural norms. The government saw Māori culture as picturesque and thus suitable for tourists, or for showcasing New Zealand's supposedly superior race relations. In particular, Rotorua was touted as 'New Zealand's leading tourist region' famed not only for its thermal attractions, but also the accessibility of its Māori community and culture. ${ }^{81}$ Early in their tour a small part of the Indian contingent accompanied the imperial troops to Rotorua to view geysers. Inevitably the local Māori welcomed the visitors with a haka.

The grotesque faces of the Maori dancers who chanted their haka in front of them seemed to amuse [the Indians] considerably, and some even unbent so far as to "salaam" to the Maori wahines [women] and smilingly ejaculate their one phrase of Maori - "Tena-koe.,"82

While the Auckland Star's account tries to evoke a sense of the 'wild' other, it shows that the Indians were happy to greet the local Māori, and make an attempt at communication, a necessary precursor to forming closer bonds and affinities.

Māori, given the role of addressing the visiting troops, asserted ethnic pride through a discourse of loyalty to the empire, which was inclusive of the Indian people. In 1901 the world's focus was on the Boer War, and the exclusion of Māori from the conflict was felt as a slight of their rights and duties of imperial as well as national citizens. Hōri Ngātai, a Ngāiterangi chief and orator, addressing the imperial troops as well as the Indians at Rotorua, acknowledged that he had 'fought against the red coats' in the past (at the Battle of Gate Pā, 1864) but that Māori were now united with the empire. He then touched on an issue that concerned both Indians and Māori, of 'how anxious we, the Natives, are to go and fight against the Boers'. ${ }^{83}$ Similarly, James Carroll, a 'half-caste' politician, also raised the exclusion from the war in his speech to the Indian troops at Gisborne. Speaking 'on behalf of the district, and especially on behalf of those who claim nativity', he informed the Indian visitors:

You have not been called upon, neither have we of the Maori, to do our duty; but we are pausative powers, which, when the time arrives, I have not the slightest doubt, we will exemplify our force, and show to the world that the prestige which has been handed down to us from our ancestors, that we can maintain it, and maintain the integrity of the British Empire. ${ }^{84}$

What the listening Indians thought of their exclusion from the war is unknown, but it is clear that for Māori the Indians' visit illuminated subtexts beyond mere imperial jingoism or spectacle. ${ }^{85}$ The patriotism of Māori was popular with their Pākehā contemporaries but also allowed them to participate as part of the wider multi-cultural imperial family as well as national citizens. 
On the morning of 21 February 1901, the SS Dalhousie, a 'smart yacht-like vessel' of the Royal Indian Marine Service, steamed into the port of Gisborne on the east coast of New Zealand's North Island, before the 90 officers and NCOs of various regiments of the Indian Army were brought to shore on a steam launch. ${ }^{86}$ Gisborne in 1901 comprised 'about 2700 inhabitants', and was the major town of the Poverty Bay district. Another 6393 Pākehā and 1808 Māori lived in the neighbouring Cook County. ${ }^{87}$ The people of the district, both Pākehā and Māori, were waiting in anticipation of an exceptional occasion. The local daily, the Poverty Bay Herald, which had kept its readers informed of the tour, subsequently covered the event, as did the monthly Anglican Māori newspaper, Te Pipiwharauroa.

Although Tamahau Mahupuku saw the Indians on parade in Sydney, none of the newspaper accounts disclose whether he had actually met the Indians there. At Gisborne, 'in his faultless frock coat and his bell topper', he was able to experience a closer encounter with the troops. According to the Poverty Bay Herald, at Gisborne,

he was the centre of admiring groups of local Natives, and took great trouble to explain to them the habits, customs, and traditions of our visitors. His eloquence of voice and gesture proved irresistibly attractive to the Indians themselves, and kept the Natives fully interested. At one time he became so warmed up to his subject that he commenced the preliminary steps of the Maori haka, by himself. Then, seeing that a number of the Indian visitors were watching him intently, he turned and explained a number of the characteristics of his own race to them. The tatooing [sic] was naturally an interesting feature of Maori habits, and the explanation of this was given by Tamahau in his own striking and graphic manner. ${ }^{88}$

Mahupuku saw himself as a cultural interpreter, first of Indian customs to the local Māori, then of Māori custom to the Indians. What knowledge he had of the former is not known. Mahupuku generally used interpreters when talking with Pākehā, so it is difficult to tell how effective his exposition of the latter might have been. ${ }^{89}$

A Māori element was an important feature of the planned program for the Gisborne visit. With the town unable to provide a feast due to the Indians' dietary restrictions, the Poverty Bay Herald considered that the Indians could still enjoy good entertainment, and 'the best manner of providing that would be to secure the hearty co-operation of the Maoris, and to arrange a liberal programme of war dances' ${ }^{90}$ The other highlight for the Indians was to be the Poverty Bay Turf Club's race day. ${ }^{91}$ The chairman of the organizing committee 'asked Mr Kohere to spread the news among the Natives, in order to get a large gathering of Maoris to give them a Native welcome'. ${ }^{92}$ This was not unusual: Gisborne Pākehā had asked local Māori to participate with performances in other celebrations, such as the fall of Pretoria, and on at least one occasion they had composed a special haka - to celebrate the exploits of Lord Roberts, the leading British general in South Africa. ${ }^{93}$ Kōhere informed the meeting that there was insufficient time to prepare for a 'first-class' haka. ${ }^{94}$ Nevertheless, it was decided that the Indians would parade through the town to the Recreation Ground 'where the Natives will dance their haka and then give their welcome'. ${ }^{95}$ The day before the arrival, the paper reported that 'the Natives are entering heartily into the spirit of the affair'. ${ }^{96}$

The planned Māori role did not proceed as envisaged. In a lengthy article on the day's events, the Poverty Bay Herald devoted over 3000 words to the procession and 
welcome. The Herald noted that during the procession 'a welcome [was] given to the visitors by a squad of Maoris at Miller's corner, who danced in a most excited fashion, waving branches of evergreens'. On reaching the Recreation Ground, however, everyone was in for 'a long and tedious wait' of 'fully half an hour's delay' while the Premier, Seddon, concluded government business at the telegraph office, and the audience listened to band music. Of the Māori welcome, it was reported that 'the Maoris tried to get up a war-dance, but it proved a fiasco, and at about 1 o'clock the troops were lined up, put into brakes, and taken to the races' ${ }^{97}$ Kōhere fired back a response to the newspaper explaining that 'after a considerable amount of trouble, I got together about 25 men, among whom were some of the best war-dancers in the district, and I knew once these had made a move the rest of the Natives would fall in and swell the number'. However, a member of the organizing committee had 'told us not to give any performance, because the Premier had arrived, and it would make things so late - so late, as I afterwards found out, for the races'. ${ }^{98}$

Kōhere would have been annoyed on a number of levels. On a personal level, he would have felt slighted. He was respected, well educated, fluent in both Māori and English, and fulfilled a role as intermediary between the two ethnic groups in the local community, bringing the modern world to Māori through the pages of Te Pipiwharauroa, and sometimes interpreting his chief's speeches to Pākehā audiences. In his role as clergyman and editor of a church newspaper, he was firmly against gambling, and would have resented having been passed over for horse racing. ${ }^{99} \mathrm{He}$ was angry at having organized performers and then being stopped, 'while we were actually putting on our mats'. ${ }^{100}$ At a time when Māori occupied a marginal space in New Zealand society, the performance was their opportunity to assert in the public sphere their legitimacy as citizens of the town, country and empire. This symbolic significance aligned with Kohere's other role as an unofficial spokesperson for the Young Maori Party. Honouring the Indian guests allowed inclusion within a mainstream Pākehā event while still proudly projecting a non-white ethnic identity. That the intended recipients of the performance were fellow 'natives', yet still esteemed by the white majority, no doubt would have been an added bonus.

It was in his own newspaper that Kōhere wrote an extensive article on the day, in which he explained the 'fiasco' over the haka. They had been pestered to perform, and 'it would have taken place if we had not been tricked by one of the people of the Committee. That Pākehā was in charge of the horse racing that day, and in his eagerness for people to go to the races told us not to perform the haka. Our haka would have been good'. ${ }^{101}$ Importantly however, 'the Indian soldiers, and Colonel Dadbha, were very sad at not seeing the haka'. ${ }^{102}$ Despite the main Māori attraction having been aborted Kōhere accentuated the Māori role in the celebration where he could. 'The Whataupoko band, most of the members Māori, were right in front of the Indian soldiers. On Gladstone Road some kuia [old women] stood to welcome the guests, and those kuia were acknowledged by the Pākehā'. ${ }^{103}$ Although Carroll represented the European parliamentary seat of Waiapu rather than the Māori seat, Kōhere stated that 'the speech of James Carroll was good, [he is] our man, the Māori's man in a high position'. ${ }^{104}$ In what was largely a settler-organized event, the haka by Gisborne Māori was to have played a special role. For Pākehā the performance made the event distinctive to New Zealand. For Kōhere and other Māori who wanted to engage with the wider mainstream society, cultural display was a means to participate on their own terms. When the Māori centrepiece was dropped, Kōhere was forced to highlight other aspects of Māori involvement. ${ }^{105}$ 
Although much of Kōhere's article resembles that of the English-language press, discussing the brilliance of the uniforms, the 'strange customs' regarding food, the dashing Colonel Dadbha, and the imperial ideal of many races under one monarch and flag, it also shows that he may have got a little closer to the Indians than some of his Pākehā contemporaries. Of all the newspaper accounts, Kōhere's gives the most information on the Indian servants, directly comparing them to the troops.

Each officer has a servant. ... The servants' job is to cook food, and look after the saddles and horses of their masters. The servants' appearance is different to the masters'. The masters are large and attractive, while the servants are small and their appearance is of no account. The clothes of the masters are very fine, using all the colours of the rainbow, gleaming with gold; the servants' clothes are thin and just nasty, and some wear no socks. ... When the master gets on the horse, the servant goes and cleans his boots and leggings, and tidies things on the saddle ... The masters and lower class do not sit together [to eat]. ${ }^{106}$

It is unclear why Kōhere felt the need to discuss the servants at all, as he was not particularly sympathetic towards them. If the native servants were set a lower rank in the scale of humanity, did this indirectly reflect on the supposed elevated status of Māori compared to other Indigenous peoples, or the more egalitarian New Zealand society? Kōhere also spoke to Dadbha, and appears to have been the only correspondent to elicit the information that the Colonel would rather have not gone touring at all, as travel did not agree with him. Quite possibly small provincial towns such as Gisborne, with unpaved streets and unsophisticated inhabitants, would have held little appeal. One can only wonder what else the two men may have discussed. ${ }^{107}$

Although Kōhere was university educated and fluent in English, the nature of Māori-language lexicon of the time coupled with the prevalent colonial discourses meant that Māori may have read and understood the texts about the Indians in different ways to Pākehā. The word 'māori', for example, through the nineteenth century was used specifically for the Māori people in a New Zealand context, but was also employed to translate more generically the term 'native'. ${ }^{108}$ Indians, along with other Indigenous peoples, were routinely described as māori which may have contributed to a greater sense of shared indigeneity than if a separate term had been used. ${ }^{109}$ Although Kōhere stated that 'some [of the visiting soldiers] are fair skinned, some are deep black', in other articles Indians more generally were described as mangumangu (black). ${ }^{110}$ When discussing the relationship between the officers and servants, Kōhere labelled them as rangatira (chief) and pononga (servant/slave), traditional cultural terms. Similarly when discussing the issues of food and caste, he stated:

They do not eat cows or pigs, but with sheep and birds, it is they who kill and cook them. This is a tikanga [custom] their ancestors handed down to them; if this tikanga is broken, the tapu [spiritual power] of the person is gone, and he is excluded from his community and despised. ${ }^{111}$

Although previously Te Pipiwharauroa had written disparagingly about Indian religion, Kōhere removed the otherness of the Indian visitors by explaining their religious difference in cultural terms of tikanga and tapu that were more familiar to Māori. ${ }^{112}$ As with the Pākehā papers, the imperial moment was stronger than the missionary imperative to convert the heathen. 
Kōhere could clearly see some irony in the Pākehā celebration of the Indian troops. In the following month's issue of Te Pipiwharauroa, inserted amongst a series of short moral and religious statements, his words sit starkly: 'Some Pākehā are contemptuous of native races, calling them paraki nika [black niggers] [but] when the Indian soldiers came here, they followed behind the paraki nika'. ${ }^{113}$ Despite the Young Maori Party's desire for racial inclusion, Kōhere had no qualms about his newspaper discussing the faults of Pākehā (especially their greed for Māori land), or white racism overseas (such as the mistreatment of blacks by Boers or Americans), but this was unusual in exposing such attitudes in New Zealand. ${ }^{114}$ Kōhere, like the Pākehā press, racialized the Indian troops but he did so in order to accentuate an Indigenous affinity with them, a position that reflected light on the place of Māori within New Zealand.

\section{Conclusion}

The expansion of empire facilitated the mobility of its people. It was the British who went across the seas to take control of Australia, New Zealand and parts of India from the respective Indigenous peoples of those lands, so the inevitable encounters between colonizer and indigene have been generally envisaged as situations in which the balance of agency lies firmly with the mobile European rather than the static 'native'. Recent historiography, attempting to disturb colonial myths, has sometimes characterized these interracial meetings within the empire as 'fractious and chaotic encounters that ... sponsored historically specific, and often politically unsettling, forms of intimacy'. ${ }^{115}$ However, the very success of colonial empires that facilitated the shipping of goods to its various parts also allowed the passage of people, not just from the centre out, but also from its peripheries to other parts, allowing mobile 'natives' to initiate intimacies with others. When people from two different Indigenous groups meet, it requires at least one to have been mobile. In the case of this essay, the celebrations of the Australian Federation allowed Māori chiefs to travel to Sydney where they met Aborigines who had travelled from their own lands in Queensland; Māori and Indian soldiers from their respective home countries to mix together at the same event; and the same Indian soldiers to encounter Māori as they paraded around New Zealand.

From the perspective of the Indigenous travellers, the circumstances from which these encounters emerged, the Federation celebrations and tour, were orchestrated and constrained. Aborigines were imported from Queensland to represent part of the natural world claimed by Captain Cook; the Māori chiefs and troops formed part of the official party of New Zealand dignitaries and military contingent; and the Indian troops (and to some extent the Māori) provided some concrete evidence of 'martial races' fortuitously now loyal to the British crown. Together they embodied the principle of a harmonious empire composed of a family of various races, vital and exotic, the painted Aboriginal people with their weapons, the Māori ready to haka, and the Indians in their vibrant colourful uniforms redolent of the sumptuous Orient whence they came. These were 'others' within the ideal white Australian or New Zealand societies, but acceptable when kept within bounds and affirming the dominant colonial and imperial ideologies.

Yet the presence of these Indigenous men allowed for some unscripted encounters between them that potentially troubled their defined roles. The Pākehā newspapers were alert to fraternization between the groups, and where possible to suggest that 'the similarity of hue constituted no special bond of intimacy between 
them', or that cultural differences between the groups were difficult to surmount. ${ }^{116}$ Certainly the interaction reported between the Māori chiefs and the Queensland Aborigines does not appear to have been close: the Aborigines supposedly judged the Māori negatively for their appearance, and Tamahau Mahupuku considered his traditional weapon, a symbol of his chiefliness, to have been of superior manufacture to those of the Aborigines. Māori were keen to interact with the Indians at Sydney, Rotorua, and Gisborne, utilizing (or attempting to utilize) the haka, a cultural expression that was generally well received among foreign audiences. At least on some occasions the Indians were receptive to Māori, even using the Māori greeting that they had learnt.

In Te Pipiwharauroa Kōhere - writing in te reo Māori for a Māori audience discusses Gisborne Māori's encounter with the Indians. Although Māori intellectuals could be just as jingoistic as Pākehā, the prevailing discourse that proclaimed that 'native' peoples formed part of the larger imperial family ensured that they saw themselves sharing with the Indians a common status different to that of whites. Carroll similarly stressed the shared injustice of being excluded from serving the empire in South Africa. The imperial discourse of racial fraternity held the promise of equality and inclusion, something that Kōhere and others in the Young Māori Party were also striving for in New Zealand. ${ }^{117}$ That Pākehā were celebrating the 'native' Indians as honoured guests made the Indigenous link all the more attractive.

We cannot be certain what the Indian soldiers made of their visit to New Zealand. Did they share the same sense of connection with Māori, either in terms of indigeneity or in imperial fraternity, as some Māori felt with them? Would the haka have appeared exotic to them, or merely primitive? Unfortunately, the newspapers that covered the tour sought little response from the visitors beyond polite expressions. Even Kōhere, who reported his discussion with Colonel Dadbha, was more concerned to convey the Indians disappointment at missing the haka due to local Pākehā selfishness than probing Dadbha's experiences of colonialism and racism. But perhaps that is the point. Although unscripted organic connections occurred, it was ideology that drove how such intimacy would be represented. The Indians provided a colourful spectacle that proved popular with the New Zealand public, but their visit also aligned with confident Pākehā assertions of their place within the emerging New Zealand nation and in the empire beyond, and with Māori attempts to position themselves as a people distinct from Pākehā, yet worthy of inclusion. 
I would like to thank the editors, Angela Wanhalla and Rani Kerin, and Dan Morrow who have read drafts of this essay, and offered much useful advice.

${ }^{1}$ Te Pipiwharauroa (TP), 1 March 1901, p.10. [All translations are by the author.]

${ }^{2}$ For example, New South Wales Government, Australian Federation, 1901, http://www.boardofstudies.nsw.edu.au/archives/ozid/federation1901 1.html; Helen Irving, ed., The Centenary Companion to Australian Federation, Cambridge, 1999, pp.7, 8; Stuart Macintyre, A Concise History of Australia, 3rd ed., Cambridge, 2009, pp.136-40; Neville Meaney, 'Britishness and Australian Identity: The Problem of Nationalism in Australian History and Historiography', Australian Historical Studies, 32, 116 (2001), pp.76-90.

${ }^{3}$ For example, Sydney Morning Herald (SMH), 2 January 1901, p.8.

${ }^{4}$ Poverty Bay Herald (PBH), 5 January 1901, p.3.

${ }^{5}$ For example, James Belich, Making Peoples: A History of New Zealanders From Polynesian Settlement to the End of the Nineteenth Century, Auckland, 1996; Ann McGrath, ed., Contested Ground: Australian Aborigines Under the British Crown, St. Leonards, 1995; Patricia Grimshaw, Marilyn Lake, Ann McGrath and Marian Quartly, Creating a Nation, Ringwood, 1994.

${ }^{6}$ Tony Ballantyne and Antoinette Burton, 'Introduction: The Politics of Intimacy in an Age of Empire', in Tony Ballantyne and Antoinette Burton, eds, Moving Subjects: Gender, Mobility, and Intimacy in an Age of Global Empire, Urbana, 2009, p.5. This was certainly not the case with respect to India, large numbers of whose workers and traders emigrated during the colonial period, mainly to other parts of Asia, to Africa and the Pacific. See S. Chandrasekhar, 'The Emigration and Status of Indians in the British Empire', Social Forces, 24, 2 (1945), pp.154, 157; Adam McKeown, 'Global Migration, 1864-1940', Journal of World History, 15, 2 (2004), pp.157; Radhika Viyas Mongia, 'Race, Nationality, Mobility: A History of the Passport', Public Culture, 11, 3 (1999), pp.530, 532. However, the relatively few who settled in the colonies in which white settlers predominated appear to have been the most resented.

${ }^{7}$ Tony Ballantyne, 'Te Anu's Story: A Fragmentary History of Difference and Racialisation in Southern New Zealand', in Alison Holland and Barbara Brookes, eds, Rethinking the Racial Moment: Essays on the Colonial Encounter, Newcastle Upon Tyne, 2011, p.52. ${ }^{8}$ Tony Ballantyne, 'Race and the Webs of Empire: Aryanism from India to the Pacific', Journal of Colonialism and Colonial History, 2, 3 (2001).

${ }^{9}$ For example, Joan Druett, Tupaia: Captain Cook's Polynesian Navigator, Santa Barbara, 2011; Anne Salmond, Between Worlds: Early Exchanges Between Maori and Europeans, 1773-1815, Auckland, 1997, pp.314-67; David A. Chappell, Double Ghosts: Oceanian Voyagers on Euroamerican Ships, Armonk, 1997; Helen M. Hogan, Bravo, Neu Zeeland: Two Maori in Vienna 1859-1860, Christchurch, 2003; Dorothy Urlich Cloher, Hongi Hika: Warrior Chief, Auckland, 2003, pp.125-48.

${ }^{10}$ Tim Flannery, The Explorers, Melbourne, 1998, pp.104-6; Te Waka Maori o Ahuriri, 27 July 1863, p.2; TP, 1 September 1907, pp.4-5.

${ }^{11}$ Angela Wanhalla, In/visible Sight: The Mixed-Descent Families of Southern New Zealand, Wellington, 2009, p.45; Ballantyne, 'Te Anu's Story', p.66.

${ }^{12}$ See Te Puke ki Hikurangi (TPH), 19 July 1898, p.2.

${ }^{13}$ TP, June 1901, p.13; Wanganui Herald (WH), 7 May 1901, p.2; Star (Auckland), 7 May 1901, p.1; Helen M. Hogan, Hikurangi ki Homburg: Henare Kohere and Terei Ngatai with the Maori Coronation Contingent 1902, Christchurch, 1997.

${ }^{14}$ Karen Fox suggests that transnational histories risk 'marginalising Indigenous voices, [by] exclud[ing] Indigenous experiences or that disregard the specificities of local experience and knowledge, once more lumping different groups into simplistic categories of "other".' Karen Fox, 'Globalising Indigeneity? Writing Indigenous Histories in a Transnational World', History Compass, 10, 6 (2012), p.429.

${ }^{15}$ Lachy Paterson, 'Rēweti Kōhere's Model Village', New Zealand Journal of History, 41, 1 (2007), pp.27-9. 
${ }^{16}$ Shino Konishi “'Wanton With Plenty': Questioning Ethno-historical Constructions of Sexual Savagery in Aboriginal Societies, 1788-1803', Australian Historical Studies, 39, 3 (2008), p.357.

${ }^{17}$ Alice Te Punga Somerville, Once Were Pacific: Māori Connections to Oceania, Minneapolis, 2012, p.xxviii.

${ }^{18}$ Ian McGibbon, 'The Origins of New Zealand's South African War Contribution', in John Crawford and Ian McGibbon, eds, One Flag, One Queen, One Tongue: New Zealand, the British Empire and the South African War, Auckland, 2003, pp.1-3.

${ }^{19}$ Keith Sinclair, A Destiny Apart: New Zealand's Search for National Identity, Wellington, 1986, pp.7-9; Ron Palenski, The Making of New Zealanders, Auckland, 2012, pp.104-22, $193-4$.

${ }^{20}$ For example, PBH, 8 January 1901, p.2. See also Marilyn Lake and Henry Reynolds, Drawing the Global Colour Line: White Men's Countries and the Question of Racial Equality, Melbourne, 2008, pp.143-47. Donald Denoon, Philippa Mein Smith, Marivic Wyndham, A History of Australia, New Zealand, and the Pacific, Oxford, 2000, p.255. The Immigration Restriction Act, 1901. See James Jupp, From White Australia to Woomera: The Story of Australian Immigration, Cambridge, 2002, p.8. Philippa Mein-Smith, A Concise History of New Zealand, Cambridge, 2005, p.120; Phillipa Mein-Smith, 'New Zealand Federation Commissioners in Australia: One Past, Two Historiographies', Australian Historical Studies, 34, 122 (2003), pp.315-7.

${ }^{21}$ Jacqueline Leckie, Indian Settlers: The Story of a New Zealand South Asian Community, Dunedin, 2007, pp.17-23.

${ }^{22}$ Star, 31 January 1893, p.4.

${ }^{23}$ Tony Ballantyne, 'India in New Zealand: The Fault Lines of Colonial Culture', in Sekhar Bandyopadhyay, ed., India in New Zealand: Local Identities, Global Relations, Dunedin, 2010, p.41.

${ }^{24}$ Nelson Evening Mail (NEM), 2 July 1896, p.2.

${ }^{25}$ WH, 6 October 1894, p.2; Observer, 16 January 1897, p.7. See also, Star, 14 August 1888, pp.5 and 21 September 1889, p.4; Bay of Plenty Times (BPT): 4 December 1893, p.2; Daily Telegraph (Napier) (DT), 23 September 1895, p.3; EP, 5 January 1885, p.2; 27 August 1886, p.2; 12 June 1894, p.3; Southland Times (ST), 23 November 1892, p.2; Star, 17 June 1890, p. 3 and 16 January 1891, p.4; Taranaki Herald (TH), 17 September 1894, p.2 and 27 December 1894, p.2; Tuapeka Times (TT), 28 February 1894, p.3.

${ }^{26}$ For example, PBH, 11 December 1890, p.2; 17 April 1893, p.3; 5 October 1896, p.2; 20 February 1899, p.3; 17 January 1900, p.2.

${ }^{27}$ Labour Department (Report of the), Appendices to the Journal of the House of Representatives (AJHR), 1896, H-6, p.vii.

${ }^{28}$ Leckie, Indian Settlers, p.66; Nancy Swarbrick, 'Indians - Early immigration', Te Ara - the Encyclopedia of New Zealand, http://www.TeAra.govt.nz/en/indians/2.

${ }^{29}$ Lake and Reynolds, pp.115-8.

${ }^{30}$ Ballantyne, 'India in New Zealand', p.43.

${ }^{31}$ See also ibid., pp.21, 43; Tony Ballantyne, Orientalism and Race: Aryanism in the British Empire, Basingstoke, 2002; Tony Ballantyne and Brian Moloughney, 'Asia in Murihiku: Towards a Transnational History of a Colonial Culture', in Tony Ballantyne and Brian Moloughney, eds, Disputed Histories: Imagining New Zealand's Past, Dunedin, 2006, pp.65-92; Tony Ballantyne, 'Teaching Maori About Asia: Print Culture and Community Identity in Nineteenth Century New Zealand', in Henry Johnson and Brian Moloughney, eds, Asia in the Making of New Zealand, Auckland, 2007, pp.13-35.

${ }^{32}$ Ballantyne, 'India in New Zealand', pp.36-7.

${ }^{33}$ Bernard Porter, Empire and Superempire: Britain, America and the World, New Haven, 2006, pp.17-18.

${ }^{34}$ James Bennett, 'Maori as Honorary Members of the White Tribe', The Journal of Imperial and Commonwealth History, 29, 3 (2001), pp.35, 38, 42, 49. See also W.P. Reeves, The Long 
White Cloud: Ao Tea Roa, London, 1898, p.57; Sinclair, A Destiny Apart, pp.7-9; Palenski, pp.104-22, 193-4.

${ }^{35}$ Beyond any social discrimination Māori faced, nineteenth century colonization was accompanied by war, land loss, depopulation and economic and political marginalization. Māori also were exclusively subject to specific legislation and institutions, such as alcohol restrictions, the Native Land Court and separate parliamentary seats. See Marten Hutt, Maori \& Alcohol: A History: Te Iwi Maori me te Inu Waipiro: He Tuhituhinga Hitori, Wellington, 1999, pp.42-4, 52; Richard S. Hill, State Authority, Indigenous Autonomy: Crown-Maori Relations in New Zealand/Aotearoa 1900-1950, Wellington, 2004, p.54; Alan Ward, A Show of Justice: Racial 'Amalgamation' in Nineteenth Century New Zealand, Auckland, 1995, pp.248-50; David V. Williams, Te Kooti Tango Whenua: The Native Land Court 1864-1909, Wellington, 1999; Ranginui Walker, Ka Whawhai Tonu Matou: Struggle Without End, Auckland, 2004, pp.144-5; Keith Sinclair, Kinds of Peace: Maori People After the Wars 1870-85, Auckland, 1991, pp.86-98.

${ }^{36}$ Lachy Paterson, 'Hāwhekaihe: Māori Voices on the Position of 'Half-castes' Within Māori Society', Journal of New Zealand Studies, 9 (2010), p.147.

${ }^{37}$ Intermarriage between Māori and non-Māori is discussed in Angela Wanhalla, Matters of the Heart: A History of Interracial Marriage in New Zealand, Auckland, 2013.

${ }^{38}$ Vincent O’Malley, Bruce Stirling and Wally Penetito, The Treaty of Waitangi Companion: Māori and Pākehā from Tasman to Today, Auckland, 2010, pp.36-42.

${ }^{39}$ Bennett, pp.40-1.

${ }^{40}$ The Advertiser, 6 April 1901, p.6.

${ }^{41}$ TP, 1 July 1901, p.13. The New Zealand parliamentarian, A.L.D. Fraser, also made this point while in Australia: The Advertiser, 17 January 1901, p.4.

${ }^{42}$ Ashley Gould, “'Different Race, Same Queen”: Maori and the War', in John Crawford and Ian McGibbon, eds, One Flag, One Queen, One Tongue: New Zealand, the British Empire and the South African War, Auckland, 2003, pp.119-21. Interestingly, when it was suggested that Māori soldiers within the New Zealand contingent to the 1902 coronation should assemble with the other 'native' groups, Seddon insisted that they should be with the Pākehā soldiers: TP, 1 September 1902, pp.3-4.

${ }^{43}$ Star, 8 February 1901, p.2; Otago Witness (OW), 13 February 1901, p.11.

${ }^{44}$ Otago Daily Times (ODT), 8 December 1900, p.7. Other chiefs also visited Sydney at this time. See, Australian Town and Country Journal, 12 January 1901, p.44.

${ }^{45}$ Angela Ballara, 'Mahupuku, Hamuera Tamahau', in The Dictionary of New Zealand Biography (DNZB), Vol. Two, 1870-1900, Wellington, 1993, pp. 304-6; Angela Ballara, 'Nireaha Tamaki', in ibid., pp. 359-61; Angela Ballara, 'Ratana, Tahupotiki Wiremu', in DNZB, Vol. Three, 1901-1920, Wellington, 1996, pp. 414-18.

${ }^{46}$ For example, Star, 21 January 1901, p.1; EP, 21 January 1901, p.6. A newspaper account from the New Zealander, 22 January 1901, was also printed in the Official New Zealand Yearbook, 1901.

http://www3.stats.govt.nz/New Zealand Official Yearbooks/1901/NZOYB 1901.html\#idse ct2 1154849 .

${ }^{47}$ Brisbane Courier, 1 January 1901, p.6; Western Mail, 12 January 1901, p.22. While it is not possible to definitively identify the tribal group or groups these men came from, the Brisbane Courier stated that they came from the coastal areas of Coopers Creek district.

${ }^{48}$ Clarence and Richmond Examiner, 12 January 1901, p.5; Australian Town and Country Journal, 19 January 1901, p.22. See also Western Mail, 12 January 1901, p.22.

${ }^{49}$ Star, 21 January 1901, p.1.

${ }^{50}$ Press (Christchurch), 15 January 1901, p.5; also EP, 15 January 1901, p.5.

${ }^{51}$ TP, 1 August 1900, p.11. 'Ko te iwi mangumangu o Ahitereiria tetahi o nga iwi whakamutunga mai i te ao nei, a e kiia ana ko te iwi Maori te iwi rangatira atu o nga iwi maori katoa...'

${ }^{52}$ For example in 1911 the Māori parliamentarian Wi Pere and others wrote to Te 
Pipiwharauroa, explaining their objection to proposed laws designed to stop Māori going to hotels to drink, stating 'this proposal is creating a barrier between the two races. If it is enacted, we would be made the same as the blacks of Australia, the blacks of America, and the blacks of Africa as well.' 'Ko tenei tikanga e hapai ana he araitanga i waenganui i nga iwi erua. Mehemea ka mana, ka whakaritea tatou ki nga Mangumangu o Ahitereiria, nga Mangumangu o Amerika, me nga Mangumangu o Awherika hoki.' TP, 1 December 1911, p.8. ${ }^{53}$ This resonates with Rachel Standfield's observation that negative statements from the Māori chief, Te Pahi, about the Eora Aborigines of Sydney in 1805 'operated as part of a developing racial discourse in the Australian colonies which justified Aboriginal dispossession'. Rachel Standfield, Race and Identity in the Tasman World, 1769-1840, London, 2012, p.3.

${ }^{54}$ Bruce Scates 'Mobilizing Manhood: Gender and the Great Strike in Australia and Aotearoa/New Zealand', Gender and History, 9, 2 (1997), p.296; Cameron White, 'Promenading and picnicking: The performance of middle- class masculinity in nineteenthcentury Sydney', Journal of Australian Studies, 30, 89 (2006), p.34; Melissa Bellanta, 'Transcending Class? Australia's Single Taxers in the Early 1890s', Labour History, 92 (2007), p.22; see also Star, 16 August 1890, p.12; TH, 26 April 1892, p.4.

${ }^{55}$ For example, ODT, 21 October 1899, p.5; EP, 18 January 1904, p.5. Certainly Te Pipiwharauroa approved of Mahupuku's attire, suggesting that it was like that of a Pākehā rangatira, and was something that Māori should aspire to. TP, 1 April 1901, p.10.

${ }^{56}$ For example, in the 1840s Sir William Martin, New Zealand's first Chief Justice, 'had made it a rule that no Maori should come into the house unless wearing English clothes'. Lady Martin, Our Maoris, London, 1884, p.19. Similarly, in the 1860s Reverend Buttle required Māori to wear 'European clothing' for his services. See NZH, 14 December 1867, p.6. Further examples of the civilizing significance of clothing can be found in Wellington Independent (WI), 19 May 1847, p.2; Nelson Examiner and New Zealand Chronicle (NE), 13 April 1850, p.27; Daily Southern Cross (DSC), 18 May 1860, p.1 and 3 January 1863, p. 4, 14 June 1873, p.1. NE, 17 August 1844, p.96, New Zealander, 8 November 1845, p.3; 11 July 1846, p.3; 6 November 1847, p.2. See also Jenny Carlyon and Diana Morrow, A Fine Prospect: A History Of Remuera, Meadowbank and St Johns, Auckland, 2011, p.34.

${ }^{57}$ For example, Observer, 2 October 1897, p.20; Marlborough Express, 10 March 1898, p.1; OW, 23 January 1896, p.42; 27 March 1901, p.65; 18 January 1905, p.74; New Zealand Free Lance, 3 February 1906, p.10.

${ }^{58}$ Press, 15 January 1901, p.5; EP, 15 January 1901, p.5. Although decidedly a joke, this resonates with earlier European attitudes towards Indigenous peoples. For example, Sir Joseph Banks considered keeping Tupaia 'as a curiosity', albeit not without the possibility of mutual friendship. Vanessa Smith, Intimate Strangers: Friendship, Exchange and Pacific Encounters, Cambridge, 2010, pp.179-80.

${ }^{59}$ Statistics New Zealand, The New Zealand Official Yearbook, 1901, http://www3.stats.govt.nz/New_Zealand_Official_Yearbooks/1901/NZOYB_1901.html. (This appeared originally in New Zealand Times, 22 January 1901.) Also see PBH, 7 January 1901, p.4. TP, 1 February 1901, p.12. 'Tetahi ra nui ko te whakatututanga o nga hoia, i whakatutu ai nga hoia o Ingarangi, o nga koroni, me nga hoia maori o Inia; kanapa ana te kakahu.'

${ }^{60}$ PBH, 25 January 1901, p.4.

${ }^{61}$ South Australian Register, 1 January 1901, p.6.

${ }^{62}$ Clarence and Richmond Examiner, 2 January 1901, p.4. See also Northern Star, 2 January 1901, p.4; Singleton Argus, 3 January 1901, p.4; The Clipper, 12 January 1901, p.6.

${ }^{63}$ Barry Mitcalfe, The Singing World: Maori Poetry, Wellington, 1974, p.177. There has been little cultural history of Māori performing arts in colonial New Zealand society. Some examples include: Mitcalfe, The Singing World; Mervyn McLean, Maori Music, Auckland, 1996; Karyn Paringātai, Poia mai taku poi - A history of poi: A Critical Review of Written Literature on the Poi in New Zealand and the Pacific, Saarbrücken, 2009. 
${ }^{64}$ EP, 21 December 1900, p.5.

${ }^{65}$ Clutha Leader, 4 March 1892, p.3.

${ }^{66}$ For example, when it was suggested that the Duke of York might visit Gisborne in 1901 (he did not), Te Pipiwharauroa recommended that local Māori learn and practice haka for the occasion. TP, 1 February 1901, p.7. See also, EP, 7 April 1900, p.1; Manawatu Standard, 30 March 1900, p.3.

${ }^{67}$ See TP, 1 April 1900, p.12; 1 May 1902, p.4; 1 June 1901, p.6.

${ }^{68}$ Star, 11 February 1901, p.5; 12 February 1901, p.1; 16 February 1901, p.5; PBH, 13 February 1901, p.3; 21 February 1901, p.2; OW, 13 March 1901, p.34. Images from the Auckland Weekly News can be accessed at the 'Sir George Grey Special Collections, Auckland Libraries', http://www.aucklandcity.govt.nz/dbtw-wpd/heritageimages/.

${ }^{69}$ Heather Streets, Martial Races: The Military, Race and Masculinity in British Imperial Culture, 1857-1914, Manchester, 2004, pp.117-8. See also David Omissi, The Sepoy and the Raj: The Indian Army 1860-1940, Basingstoke, 1994, pp.12-13.

${ }^{70}$ Star, 9 February 1901, p.5 and 11 February 1901, p.5.

${ }^{71}$ PBH, 21 February 1901, p.2.

${ }^{72}$ For example, PBH, 16 February 1901, p.2 and 4 March 1901, p.3; Star, 9 February 1901, p.5; 19 February 1901, p.3; 14 February 1901, p.5; New Zealand Illustrated Magazine, 1 March 1901, p.490; Wanganui Chronicle, 18 February 1901, p.2.

${ }^{73}$ PBH, 21 February 1901, p.2. In particular Seddon disliked Chinese. See R.M. Burdon, King Dick: A Biography of Richard John Seddon, Christchurch, 1955, pp.43, 78-80.

${ }^{74}$ For example, Star, 7 August 1897, p.3; 29 July 1899, p.5; 8 October 1901, p.5; ST, 3 May 1900, p.4; 5 May 1900, p.3; Colonist, 25 September 1906, p.4; Bruce Herald, 18 September 1885, p.6; OW, 23 November 1893, p.42; WH, 29 November 1893, p.2; NEM, 13 October 1891, p.4. See also PBH, 16 February 1901, p.2; 18 February 1901, p.2.

${ }^{75}$ PBH, 21 February 1901, p.2.

${ }^{76}$ Star, 13 February 1901, p.8.

${ }^{77}$ Star, 8 March 1901, p.1.

${ }_{78}^{78}$ PBH, 19 February 1901, p.4.

${ }^{79}$ PBH, 11 March 1901, p.4.

${ }^{80}$ OW, 13 March 1901, p.3.

${ }^{81}$ Margaret McClure, The Wonder Country: Making New Zealand Tourism, Auckland, 2004, pp.19-20.

${ }_{82}^{82}$ Star, 18 February 1901, p.2.

${ }^{83}$ Ibid.

${ }^{84}$ PBH, 21 February 1901, p.2.

${ }^{85}$ Some South African-based Indians (including Gandhi) did form a non-combatant Volunteer Ambulance Corps. In India, some newspapers did criticize the imperial decision to exclude Indian troops based on race. See Pradip Kumar Datta 'The Interlocking Worlds of the AngloBoer War in South Africa/India', South African Historical Journal, 57, 1 (2007), pp.40, 53. Indigenous Indian servants and grooms were also part of Lumsden's Horse, a European volunteer corps from India, but not as combatants. Henry H.S. Pearse, The History of Lumsden's Horse: A Complete Record of the Corps from its Formation to its Disbandment, London, 1903, p.34.

${ }^{86}$ Star, 11 February 1901, p.5.

${ }^{87}$ AJHR, 1901, H-26b, p.21; Statistics New Zealand, The New Zealand Official Year-Book, 2001, http://www3.stats.govt.nz/New_Zealand_Official_Yearbooks/1901/NZOYB_1901.html. ${ }^{88}$ PBH, 16 February 1901, p.2

${ }^{89}$ Tamahau Mahupuku often used interpreters when talking or giving speeches to Pākehā. See EP, 3 October 1888, p. 4; 26 October 1897, p. 2; Hawkes Bay Herald (HBH), 6 July 1892, p.2; 13 March 1900, p. 3; Wairarapa Daily Times, 5 April 1902, p.3; SMH, 2 February 1901, p. 10 .

${ }^{90}$ PBH, 16 February 1901, p.2. 
${ }^{91}$ PBH, 20 February 1901, p.2.

92 ibid.

${ }^{93}$ TP, 1 June 1900, p. 6; 1 July 1900, p.8.

${ }^{94}$ PBH, 18 February 1901, p.2.

95 ibid.

${ }^{96}$ PBH, 20 February 1901, p.2.

${ }^{97}$ PBH, 21 February 1901, p.2.

${ }^{98}$ PBH, 23 February 1901, p.4.

${ }^{99}$ For example, TP, 1 April 1900, p.3; 1 May 1902, p.1; 1 July 1902, p.10.

${ }^{100}$ PBH, 23 February 1901, p.4.

${ }^{101}$ TP, 1 March 1901, p.10. 'Engari ra e tu tonu ana he haka mehemea kaore matou i

tinihangatia e tetahi tangata o te Komiti. Ko taua pakeha he tumuaki no te reihi hoiho i taua

ra, a i tona whaawhai kia haere nga tangata ki tona reihi ka kiia mai e ia kia kaua e haka. Tera tonu e pai ta matou haka.'

${ }^{102}$ ibid., 'I tino pouri nga hoia o Inia, a Kanara Tatapa, i to ratou korenga e kite i te haka.'

${ }^{103}$ ibid., 'Ko te peene o Whataupoko, he maori te nuinga o nga tangata, i mua tata atu o nga hoia o Inia. I Karatitana Rori ka tu etahi kuia ki te powhiri i te manuhiri, i whakamihia aua kuia e te pakeha.'

104 ibid., 'Pai ana te whai-korerotanga o Timi Kara, to taua nei tangata to te Maori kei te turanga tiketike.'

${ }^{105}$ This was a recurrent theme within the newspaper. For example, the paper mentioned three times in one issue that at the opening of the Australian Parliament in Melbourne in May 1901, Māori soldiers had been given the honour of being placed at the side of the Duke of York's carriage. TP, 1 June 1901, p.13.

${ }^{106}$ TP, 1 March 1901, pp.9, 10. 'He pononga to tena apiha to tena apiha. ... Ko te mahi a nga pononga he tunu kai, he tiaki i nga tera, i nga hoiho o ratou rangatira. Rere ke ano te ahua o nga rangatira i nga pononga. He nunui he ataahua nga rangatira ko nga pononga he pakupaku he hauwarea noa iho te ahua. Ko nga kakahu o nga rangatira tino pai atu, i pau katoa nga kara o te aniwaniwa, i uwirawira i te koura; ko nga kakahu o nga pononga he rahirahi, he whakarihariha noa iho, kaore he tokena o etahi. ... Ka eke te rangatira ki te hoiho ka haere atu te pononga ki te horoi i nga puutu i nga rekene, ki te whakatikatika hoki i nga mea o te tera. ... Kaore e noho tahi nga rangatira me nga ware.'

${ }^{107}$ Kōhere does not discuss any further fraternization between Māori and the Indians. This may have been difficult in some cases as not all Māori or Indians possessed good English language skills.

${ }^{108}$ Lachy Paterson, 'Kiri Mā, Kiri Mangu: The Terminology of Race and Civilisation in the Mid-nineteenth Century Maori-Language Newspapers', in Jenifer Curnow, Ngapare Hopa and Jane McRae, eds, Rere atu, Taku Manu! Discovering History, Language and Politics in the Maori-language Newspapers, Auckland, 2002, p.82.

${ }^{109}$ For examples of Indians being referred to as māori, see TP, 1 April 1900, p.1; 1 May 1900, p.8; 1 February 1901, p.12; 1 March 1901, p.9; 1 July 1902, p.7.

${ }^{110}$ TP, 1 March 1901, p.9. See also, TP, 1 July 1899, pp.9, 10; 1 August 1900, p.10; 1

February, 1901, p.7.

${ }^{111}$ TP, 1 March 1901, p.10. 'Kaore ratou e kai i te kau i te poaka, engari te hipi te manu, ma ratou ano e patu e tunu. He tikanga tenei na o ratou tupuna tuku iho nei ki a ratou ; ki te he tenei tikanga ka ngaro te tapu o te tangata a ka wehea atu ki waho o tona whakaminenga ka whakahaweatia.'

${ }^{112}$ TP, 1 August 1898, pp.3-4.

${ }^{113}$ TP, 1 April 1901, p. 8. 'E whakakino ana etahi pakeha ki nga iwi maori, e mea ana, "he paraki nika," no te taenga mai o nga hoia o Inia, ka whaiwhai haere hoki i te "paraki nika.",

${ }^{114}$ For example, TP, 1 December 1899, p.12; 1 June 1901, p.10; 1 November 1902, p.8. See also TP, 1 April 1900, p.6; 1 September 1900, p 7; 1 January 1901, p 8; 1 August 1902, p.4; 1 October, 1907, p.1; 1 September 1908, p.1. 
${ }^{115}$ Ballantyne and Burton, p.4.

${ }^{116}$ PBH, 25 January 1901, p.4.

${ }^{117}$ Carroll and the Young Māori Party parliamentarians Āpirana Ngata and Māui Pōmare coordinated the Māori war effort during the First World War. See O'Connor, 'Recruitment of Maori Soldiers', passim. During the Second World War, Ngata published a book celebrating the exploits of the Maori Battalian and V.C. recipient, Te Moananui-a-Kiwa Ngārimu, entitled The Price of Citizenship: Ngarimu V.C., Wellington, 1943. 